\title{
Renewable Energy Cooperatives as Solution to Enhance Electrification and Economic in Developing Region
}

\author{
Ade Hilmy Maulana Achzab ${ }^{1, *}$, Iqbal Ridalta Putra ${ }^{1}$ \\ ${ }^{1}$ Bandung Institute of Technology \\ Received July $17^{\text {th }}, 2018$; accepted February $27^{\text {th }}, 2019$ \\ Available online February $28^{\text {th }}, 2019$
}

\begin{abstract}
Indonesia is the nation with abundant of natural resources. Natural resources itself in kind of crude oil, natural gas, coal, geothermal, hydropower, wind, and biomass become the commodity which is targeted to enhance economic development by utilizing them as the object for electrical supply in Indonesia, especially for nation electricity need. In Indonesia, the index for electrification reaches up to $94.91 \%$ in 2017 and continuously increasing year by year. It is contrary to regional electrification index as some developing region still far below $80 \%$, even though those region have a huge amount of renewable resources potential, ranging from, solar, water, biomass, wind, geothermal as well as garbage. That potential does not go in line with renewable energy power plant which counts to $1 \%$ of total energy source. It can be analyzed that it happen because the inavailability of technology and social-political activity in Indonesia. Other than that, the system of centralization of electrical provision inhibit the potential of each region that could directly handled by local society. Therefore in this paper we propose a solution in form of renewable energy cooperatives (REC). REC applies the system of people economy to enhance the power plant establishment. REC would give capital to local society that comes from their own, to establish their own power plant. This allows the shifting to decentralization to optimize region potential and help government to reach the goal of electrification in Indonesia and plays major role in transforming Indonesian economic.
\end{abstract}

Keyword : Renewable Energy Cooperatives, electrification, decentralization, renewable energy, developing region, society's characteristic, legal

\section{Introduction}

Indonesia is the nation with abundant of natural resources. Natural resources itself in kind of crude oil, natural gas, coal, geothermal, hydropower, wind, and biomass become the commodity which is targeted to enhance economic development by utilizing them as the object for electrical supply in Indonesia, especially for nation electricity need. In Indonesia, the index for electrification reaches up to $94.91 \%$ in 2017 and continuously increasing year by year (ESDM, 2017). It is targeted that in 2020, the ratio of electrification reaches $100 \%$ which means that all the regions in Indonesia has already been installed the power plant to suffice society need. According to the data issued by ESDM, the energy resources used is shown by graph below:

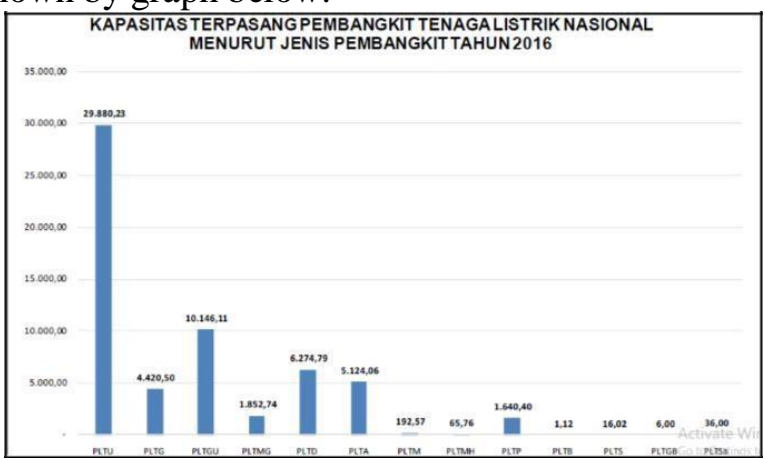

Figure 1.1 The Utilization of energy resource from Kajian ESDM 2017

\footnotetext{
* Corresponding author

E-mail address: adehilmy23@gmail.com
} 
From the data, steam power plant that uses fossil-based material site the first place with $29,888.033$ followed by geothermal, gas and steam, gas machine, diesel respectively with 4.420,5 MW, 10.146,11 MW, 1.852,74 MW, dan 6.274,79 MW. It can be simplified that the diversification of renewable energy resources low-classified for electrical need. It is contrary to the high-potential amount of resource the nation which values up to 500,000 MW (ESDM, 2017). With such amount of resource, if being used optimally it could resolve the pollution effect caused by the use of excessive fossil fuel. The environmental effect itself varies from the increase of green house effect $(\mathrm{CO} 2)$ that leads to global warming.

This effect could harms the environment in both short time and long time period. Several nation has already conduct a series of energy policy in national as well as international level through agreements, one of them named as Paris Agreement. The use of renewable energy becomes a must to be applied in transportation, industry, householding and many other sectors (Donny, 2014). In Indonesia, the potential of renewable resources not yet optimally utilized. This can be reflected by the low number of electrical-on duration in developing region especially in border line of Indonesia. So far, it is PLN as the state-owned enterprise that take care the problem.

Solution comes to mind to tackle these abandoned resources can be formulize in form of independent power producer. This allows society to be indirectly enforced to accept renewable energy as resources to supply daily electrical needs. In other side, this also urge a more decentralized system to pursue the transformation in society itself. The grassroot innovation can also be defined as network of activists and organization to emerge a bottom-up solution for sustainable development . Some scholars have already evaluated that kind of eaning in transformation. They are about several factors which are: characterize that grassroot initiatives addressing how they are mobilizing value in society contributing much to them. At the end, this will lead the transformation to the goal of sustainable development and pursuing justice for the society especially in terms of energy.

Another side to be examined by us are the problem faced with the use of this renewable energy utilization. In short, we can say that it engulfs two main factors: social and politic that influence the readiness of technology, economical level and capital problem (Pellicer-Sifres, 2018). It implies that to force the transformation happening, required not only transition of social behavior but also technological and political transformation (Pellicer-Sifres, 2018). It can be explained as the current technology int the world can be imported to handle this problem, but in other side there also restriction from law not allowing this to happen. In society itself, there should emerge a new business model and new actor to challenge the market structure.

Renewable energy cooperatives with bottom-up and collective solution properly resolve the problem in local and global issue, those are: electrification, resources utilization, and global climate change. This allows transition accelerates faster as the direct participation of individuals in the electricity acts as proactive agent of change rather than being recipients of electricity from centralized system. In this paper, problem discussed includes all things aforementioned above as well as the capital seeking and society development through acitivities that indirectly help them to achieve the welfare and helps the sustainability of renewable cooperatives itself.

\section{Theory}

\subsection{Renewable Energy}

Renewable energy is the energy that obtained from renewable resource, that can be used repeatedly and replaced naturally in long period of time.It encompasses hydropower, wind, solar, biomass and geothermal. Renewable energy also includes into ebt, likely we take garbage as an example of that. The development of this EBT basically initiated by environmental problem emerges due to waste and pollution produced by fossil-based energy (Donny, 2014). The excessive use of fossil-based energy could harm the balance of environment and repressive act needed to prevent disaster facing the world: global warming that leads to climate change. Though the use of EBT implied several disadvantages, 
we could not deny that EBT is environmentally friendly (Donny, 2014). The force of such environmental-friendly energy is a must as the consuming and producing of fossil-based influence the balance of environment. Fossil burning results in $\mathrm{CO} 2$, the greenhouse gas that contributes to global temperature rises. In the middle of 2013, the greenhouse effect reach its maximum point in last 2millions years due to electrification and transportation activity. The real problem faced determiningly urges government and society to use EBT as alternative resoures (Donny, 2014) Indonesia has abundant of EBT resources, as $>500,000 \mathrm{MW}$ them exist in the whole nation. Unfortunately, only 5\% of them are utilized. The resources potential itself exist not only in Java as the central economic activity land but also the developing region These are the data of EBT in Indonesia:

\section{Geothermal}

With 29 GW potential or equal to $20 \%$ of total electrification in Indonesia. Only $1400 \mathrm{MW}$ hitherto installed.

Table 2.1 Geothermal Potential by ESDM,2017

\begin{tabular}{|c|c|c|c|}
\hline No & Island & $\begin{array}{l}\text { Number of } \\
\text { Location }\end{array}$ & $\begin{array}{l}\text { Total of probable, possible } \\
\text { and proven (MW) }\end{array}$ \\
\hline 1 & Sumatera & 93 & 12.886 \\
\hline 2 & Jawa & 73 & 9.795 \\
\hline 3 & Bali - Nusa Tenggara & 33 & 1.907 \\
\hline 4 & Sulawesi & 76 & 3.229 \\
\hline 5 & Maluku & 32 & 1.421 \\
\hline 6 & Kalimantan & 14 & 163 \\
\hline 7 & Papua & 3 & 75 \\
\hline & TOTAL & 324 & 29.476 \\
\hline
\end{tabular}

\section{Hydropower}

These resources has been known earlier as well as the power plant to utilize them. The potential are as much as 75,000 MW.

Table 2.2 Hydropower Potential by ESDM,2017

\begin{tabular}{|l|l|l|}
\hline No & Island & Total $(\mathrm{MW})$ \\
\hline 1. & Sumatera & $16.381,76$ \\
\hline 2. & Jawa & $12.272,02$ \\
\hline 3. & Kalimantan & $6.277,25$ \\
\hline 4. & Sulawesi & $14.717,56$ \\
\hline 5. & Bali - NTB/T & $4.931,64$ \\
\hline 6. & Maluku - Papua & $21.089,76$ \\
\hline \multicolumn{2}{|l|}{ TOTAL } & $75.669,99$ \\
\hline
\end{tabular}




\section{Wind}

Indonesia is a region with relatively low wind rate. But the potential are attracting companies to deal with.

Table 2.3 Wind Potential by ESDM, 2017

\begin{tabular}{|l|l|l|}
\hline No. & Region & Capacity (MW) \\
\hline 1. & $\begin{array}{l}\text { Lebak Area } \\
\text { (Banten) }\end{array}$ & 100 \\
\hline 2. & Garut Selatan & 150 \\
\hline 3. & Purworejo & 67.5 \\
\hline 4. & Jeneponto & 132.5 \\
\hline 5. & Sumba Timur & 5 \\
\hline Total & 455 \\
\hline
\end{tabular}

\section{Solar}

The equator region of Indonesia makes the light exposure from solar abundantly exists aand results in increasing amount of ebt.

Tabel 2.4 Solar Potential by ESDM 2017

\begin{tabular}{|c|c|c|c|}
\hline No & City & Province & $\begin{array}{c}\text { Average Radiation } \\
(\mathrm{kWh} / \mathrm{m} 2)\end{array}$ \\
\hline 1 & Banda Aceh & NAD & 4.1 \\
\hline 2 & Palembang & Sumatera Selatan & 4.96 \\
\hline 3 & Manggala & Lampung & 5.23 \\
\hline 4 & Jakarta & Jakarta & 4.19 \\
\hline 5 & Bandung & Jawa Barat & 4.15 \\
\hline 6 & Lembang & Jawa Barat & 5.15 \\
\hline 7 & Cittus Tangerang & Banten & 4.32 \\
\hline 8 & Darmaga & Jawa Barat & 2.56 \\
\hline 9 & Serpong & Banten & 4.45 \\
\hline 10 & Semarang & Jawa Tengah & 5.49 \\
\hline 11 & Surabaya & Jawa Timur & 4.3 \\
\hline 12 & Kanteng & Yogyakarta & 4.5 \\
\hline 13 & Denpasar & Bali & 5.26 \\
\hline 14 & Pontianak & Kalimant an Barat & 4.55 \\
\hline 15 & Banjarbaru & Kalimant an selatan & 4.8 \\
\hline 16 & Banjarmasin & Kalimant an selatan & 4.57 \\
\hline 17 & Samarinda & Kalimant an Timur & 4.17 \\
\hline 18 & Manado & Sulawesi Utara & 4.91 \\
\hline 19 & Palu & Sulawesi Tengah & 5.51 \\
\hline 20 & Kupang & NTT & 5.12 \\
\hline 21 & Waingapu & NTT & 5.75 \\
\hline 22 & Maumere & Papua & 5.72 \\
\hline
\end{tabular}




\section{Garbage}

In Indonesia, especially the big cities, gargabes are looked as unused material. In fact, they store a large amount of energy potential.

Table 2.5 Garbage Potential by ESDM 2017

\begin{tabular}{|l|l|l|l|}
\hline No. & Province & $\begin{array}{l}\text { Garvage } \\
\text { Production } \\
\text { (Ton/Hari) }\end{array}$ & $\begin{array}{l}\text { Energy } \\
\text { Potential } \\
(\mathrm{MW})\end{array}$ \\
\hline 1 & $\begin{array}{l}\text { DKI Jakarta, } \\
\text { Jawa Barat, } \\
\text { Banten }\end{array}$ & $\begin{array}{l}17.190 \\
\text { Jawa Tengah, } \\
\text { DIY }\end{array}$ & $11.238,3$ \\
\hline 3 & Jawa Timur & 8506 & 352,37 \\
\hline 4 & $\begin{array}{l}\text { Riau dan kep. } \\
\text { Riau }\end{array}$ & 1053 & 43,62 \\
\hline 5 & $\begin{array}{l}\text { Sumatera } \\
\text { Utara }\end{array}$ & 1812 & 75,06 \\
\hline 6 & $\begin{array}{l}\text { Sumatera } \\
\text { Barat }\end{array}$ & 682 & 28,25 \\
\hline 7 & $\begin{array}{l}\text { Sumatera } \\
\text { Selatan }\end{array}$ & 1.171 & 48,51 \\
\hline 8 & Lampung & 703 & 29,12 \\
\hline 9 & Bali & 1.245 & 51,57 \\
\hline 10 & $\begin{array}{l}\text { Kalimantan } \\
\text { Timur }\end{array}$ & 400 & 16,57 \\
\hline 11 & $\begin{array}{l}\text { Kalimantan } \\
\text { Barat }\end{array}$ & 340 & 14,09 \\
\hline 12 & $\begin{array}{l}\text { Sulawesi } \\
\text { Selatan }\end{array}$ & 1.029 & 42,63 \\
\hline TOTAL & $45.369,3$ & $1.879,59$ \\
\hline
\end{tabular}

\section{Biomass}

Biomass resources exist in Indonesia in many kind of form. Some plant i.e. palm oil, kemiri sunan, jarak pagar, corn, cassava, cane sugar, and many others are example for them. The total energy exerted by biomass itself stands for $32.000 \mathrm{MW}$ (ESDM, 2017). From the data shown above, the developing regions with such large amount of resources potential are having problem with electrification, which as much as 13,000 village hasn't yet got electrified (ESDM, 2017). This happens because social behavior and policy that leads to another problem such the lack of knowledge to energy, the lack of financial capital and readiness of technology. Therefore the solution needed is in form of economical agent that could help people in the developing region to help the funding, empowerment and leads to better electrification rate. In this paper, we called the agent as Renewable Energy Cooperatives.

\subsection{Cooperatives}

Cooperatives is an enterprise owned and managed together and operated to for the benefits of member, in this paper we examined them into energy needs. According to UU No. 251992 verse 4, Cooperative has several roles and functions as below: 
a. To build and develop the potential and ability of economic of the member in specific and society in general to increase economic and social welfare

b. Actively plays role in levelling up the human quality as well as society

c. Strengthening people economy as basic power and security with cooperative as the main pillar

d. Attempt to realize and develop national economic as collective-owned enterprise based upon kinship and economic-democracy.

In Indonesia, up till 2016, there exist 212,135 unit of cooperatives with total of members as much as 778,310 people. This model of enterprise is different with investor-owned firm or conventional firm. There is no separation between owner, employer, employee and customer because there only exist the realtion between them. International Cooperatives Alliance 7 defines cooperative as an autonomous association of persons united voluntarily to meet their common economic, social, and cultural needs and aspirations through a jointly owned and democratically-controlled enterprise. In Indonesia, the definition of cooperatives comes as more legal approach rather than business model, and basically comes from the principle of people economic.

Generally, cooperatives has the value of self-help, self-responsibility, democracy, equality and equity. Cooperatives itself in the operation focus on the benefit for the members rather that to seek the profit as much as possible. Besides the empowerment in the economic sectors, cooperatives also plays major role in social and psychological aspect in the activities. But that does not implies that, possibly cooperatives can results a large amount of profit to be shared in form of Sisa Hasil Usaha. Mubyarto (2014) states that, people might not been to happy with the role played by cooperatives in Indonesia Economy. People might wonder the clear role, so that some data are required. Cooperatives contribute small part in Indonesia GDP (estimation from Prof. Mubyarto values 2\%, while Bambang Ismawan stated around 5\%), relatively low compared to Finland 21\%, New Zealand 22\%, Switzerland $16.4 \%$, Sweden 13\% and the developing nation Kenya with $45 \%$ GDP share. It is obtained that the number of cooperatives are high, as Institute for Cooperative Research and Development (ICRD) stated that in $2012,71 \%$ of cooperatives are inactive and $22 \%$ are dying. REC could possibly lower the number as the core activities involve the basic need for society, in line with several side activities to enhance people sovereignity.

\subsection{Dynamic and Empowerment of Society in Developing Region}

\section{a. Developping Region}

Developing region is the region with society and economic activites relatively slow-developped compared to the others in national scale (Compton, 1997). It can be classified as developing if: (a) geographically bad in accessibility due to the far situation in mountain, forest, island, border of island or any other geomorphological factors therefore unable to connect with transportation and communication media. (b) From natural resources perspective, has a large amount of them but due to the legally protected situation i.e. hutan lindung not yet explored and exploited. (c) From human resources perspective, relatively has lower education, knowledge and skill level and local-costume that does not develop well with the age. There also another factors like inadequate public transportation, disastrous area, and not-inclusive policy (Compton, 1997).

One of the factors mentioned above is human resources problem. There, people usually work as farmer, merchant, fisher and any other jobs with relatively poor-dibekali knowledge that leads them to economicblind perspective, and depends on capital owner (tengkulak) present in the area (Susilo, 2015). These capital-owners would later markets the product from people in the developing region. The problem emerges with this situation is the profit obtained by tengkulak is as much as 2-3 time the 
price they buy from the people. Due to the lack of knowledge mentioned before, along with limited ability to use technology (Chambers, 1996). the welfare does not comes to the society and there should be a system to overcome it.

\section{b. Empowerment}

Empowerment means as a concept born as the part of society thought development as the impact of globalization (Muchtar, et al., 2011). According to Payne (1997:266), in principle, the empowerment is aimed to help the client increase the power to decide and act to their life by eliminating social or individual impact from external power by increasing self-confidence to use such power and transfer it from environment to the client. Zastrow (2008:412) stated that empowerment is a process to help individual, family, group, and community to improve self-development, interpersonal, socio-economy and political power to influence others. (Muchtar, et al., 2011). Kartasasmita (1996:145) defines empopwerment as a process to build the power by enforce, motivate and grow the awareness to potential owned and try to develop them. While Sumodingrat (2009) interpret the empowerment as the ability of society to to utilize the resources present I the environment to achieve the welfare. (Muchtar, et al., 2011), From several concepts stated, empowerment in general is a process to educate society to enhance the ability to utilize the resources for the sake of welfare for themselves (Martin, 2016).

\subsection{Law}

\section{a. Law product to regulates EBT}

Indonesia has already payed attention to the utilization of EBT, as stated in National Energy Policy to reduce the concentration of greenhouse effect caused bu the burning of fossil-based fuel. Later explained in detail, in derivatives of the policy, General Plan for National Energy (RUEN). In there, stated the national managing plan of energy that is the further explanation of KEN that typically a corss-sector relation to achiever the target in KEN (PLN, 2018). In UU No. 302007 about energy, it is stated the energy provision by government and/or local government prior in region that is not yet well developing, daerah terpencil, and peresaan by using local energy resources especially renewable energy.

In the utilization of energy that conducted based on the principle of beneficiality, rationality, justice efficiency, incremental of added value, continouity, welfae, conservation of life-being, national security, and harmony prior national ability. The utilization conducted by optimizing all the potential of resources by considering aspects of technology, social, economy, conservation and environment and prioritize the fulfillment of society needs and an increase in economic activities in energyresources region.

Regarding the utilization of RE for electrification, government should purchase the need from private sector as stated in Permen ESDM No. 122017 about EBT Utilization ad Electrification Provision. The law also regulates the purchase of electric from PT PLN as state-owned enterprise, nationalprivate as well as international-private.

\section{b. The Law Regulates Cooperatives}

UU No. 17 2012, explains that the purpose of the cooperatives is to increase the welfare of the members in specific and society in general as inseparable part of economic system that is democratic and justice. In the core, cooperative run all kind of activites to achieve the purpose with kinship principal. This law also replace the UU No. 251992 about cooperatives. 


\section{Methodology}

This research used descriptive-model type. Descriptive analysis method purposed to create a clear description and explanation by giving illustration systematically, factual, and accurate with the data being researched, characteristic and phenomenon-related things. This method used to give a specific concern on problem faced by developing region that has an huge amount of energy resources. The description being offered gives the fact and rational interpretation that explain relation, prediction, and getting implication of the problem. The data we obtained comes from study and document from legal body, government policy and analysis from several papers.

The intention of using this method is to determine procedure for solving the problem and gives the condition of subject and object exist. There are two steps of research: (1) literature study and (2) analysis and explanation. Literature study is the beginning process by collecting data and information from book, journal, paper and article, news about electrification and government policy. It is purposed to make a clear vision to formulate the problem. Analysis and explanation is the last step, conducted by connecting macroreality of developing region with current situation including resources potential to develop renewable energy by conducting several key acitivities.

\section{Result}

Based on the research conducted, we use the concept explained from paper by Moritz and Wolfgang (2018) entitled "Renewable Energy Cooperatives: Facilitating the Energy Transition at Port of Rotterdam" as well as the studyabout the society in developing region. We also assumed that the condition of the society in the region state (Port of Rotterdam) equivalent with the one in Indonesia. The data adopted consists of several characteristic, those are confirmed characteristic, rejected characteristic, and potential characteristic.

\subsection{Confirmed Characteristic}

These are the characteristic that should be owned by a REC :

a. Well-prepared and clear target in financial and social aspect

The establishment of the REC should clearly targeted for sustainability, which are capital income and social impact.

b. Professional

REC should be professionally managed and shall avoid the feudalism that could possibily exist in local society. This shall be examined as a legally body to strengthen the position of REC in society.

c. Having a clear and measurable vision and mission

This point is purposed to give the clear explanation to the member so that they could wellconsidering the decision to join the cooperation

d. Membership Fee

Fee amount should be well-calculated to give a rational number to member so they could sustainably maintain involvement in the cooperation.

e. Independent

REC should not be involving any other parties that could distort the vision of the REC itself. These are such political party, etc.

f. Trusted

In managing the cooperative, the board should give the regular report to the member and capital holder so that they could observe the REC well. 
g. Clear Structure and Roadmap

Boards must be a well-defined structure in job description as well as the right and duty. In other side, there should be a prepared goal-achieving steps to give a good legitimation to the boards.

h. Maintain a good relationship with stakeholder

Stakeholder plays a major role in REC establishment, as it determines relation and legal affair of the cooperatives.

\subsection{Rejected Characteristic}

a. One man one vote decision Consesus should be pursued as it represent the culture of Indonesia as stated in Pancasila point 4.

b. External Investor

This could affect the REC through conflict of interest that is not in line with the goal.

\subsection{Potential Characteristic.}

a. Strong Business Case

REC should provide this to make the investor and donator sure to run their money there.

b. Membership

Membership should encompass all the local society to give the benefit to the whole village and runs effectively without any disturbance due to jealousy.

c. Large scale

REC model can be adapted to another region and co-works to give a wider scope of advantages.

d. Matchmaker

REC should be a good 'spider webs' that connect the involved sector, those are boards itself with society, government, company and any other sector.

e. Efficient

The activities run in efficient way to minimize bireucracy and operating cost.

f. Having a good relation with external company

This aimed to widen the possible investing-party to make REC grows bigger. 


\section{Analysis}

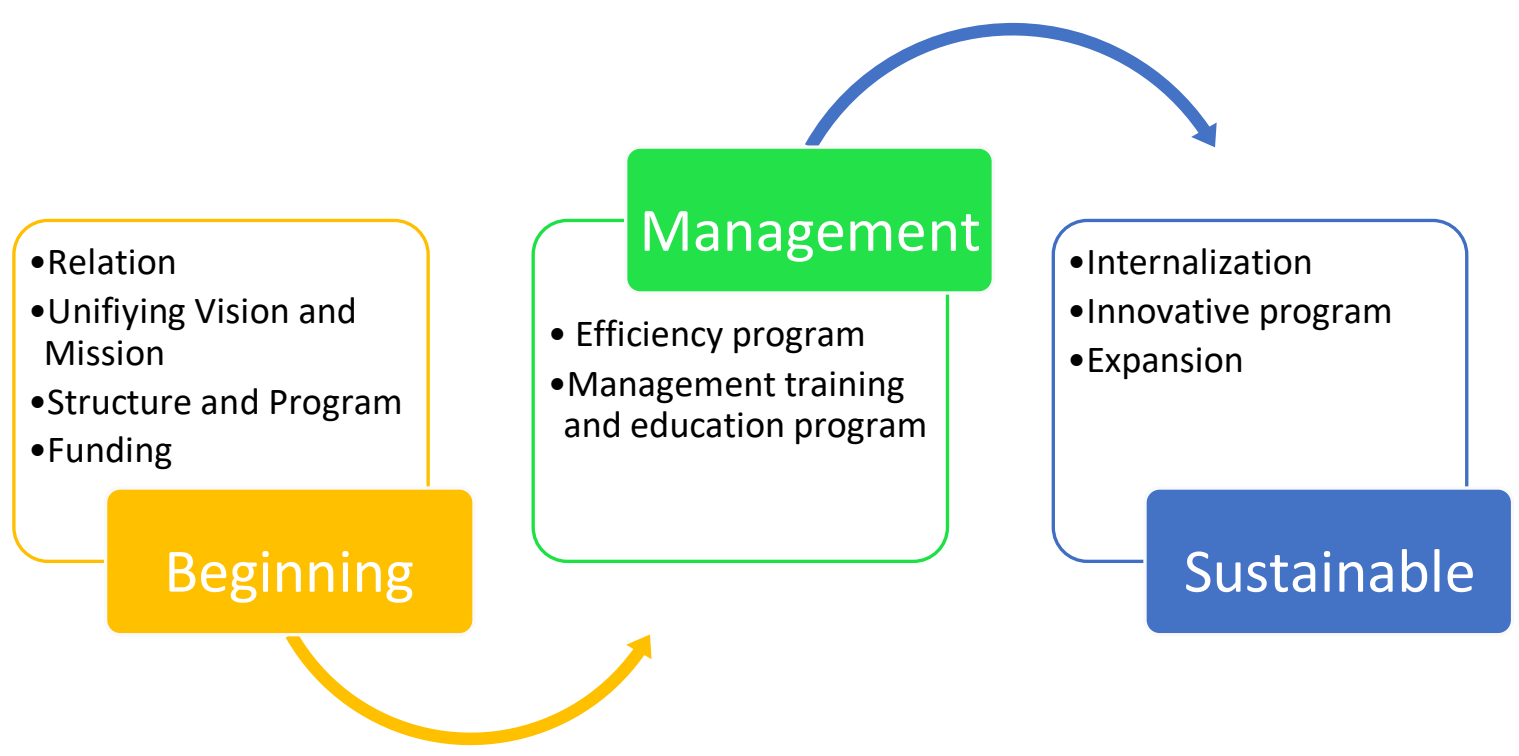

Graphic 5.1. Model of Planning REC

\subsection{Model of Strategic Planning of REC}

The model of strategic planning of REC resulted from modification of earlier REC exists.The steps consists of beginning, management, and sustainable phase. These are the explanation in detail.

\subsubsection{Beginning Phase}

1. Construct a supportive relation

Cooperative is a collective-owned enterprise that involves 2 or more members so it requires to have a relation to share the same concerns on developing REC. This also help REC to create a good vision and build a trust of inter-party.

2. Creating and unifying vision, mission and strategy.

Vision intenderly formulated to determine the orientation of REC during establishment and steps required to achieve it. This gives a clear corridor to boards to run the activities.

3. Creating structure and program

The creation of this is aimed to determine the elements being responsible to the occupation of party in REC. Not all the member should present in the structure, as those who does categorized as active meber and those who doesnot as inactive member. Structure should be personalized based on the need emerges from the member and cooperative's strategy.

Based on paper and study mentioned in previous chapter, the structure defined as follow: 


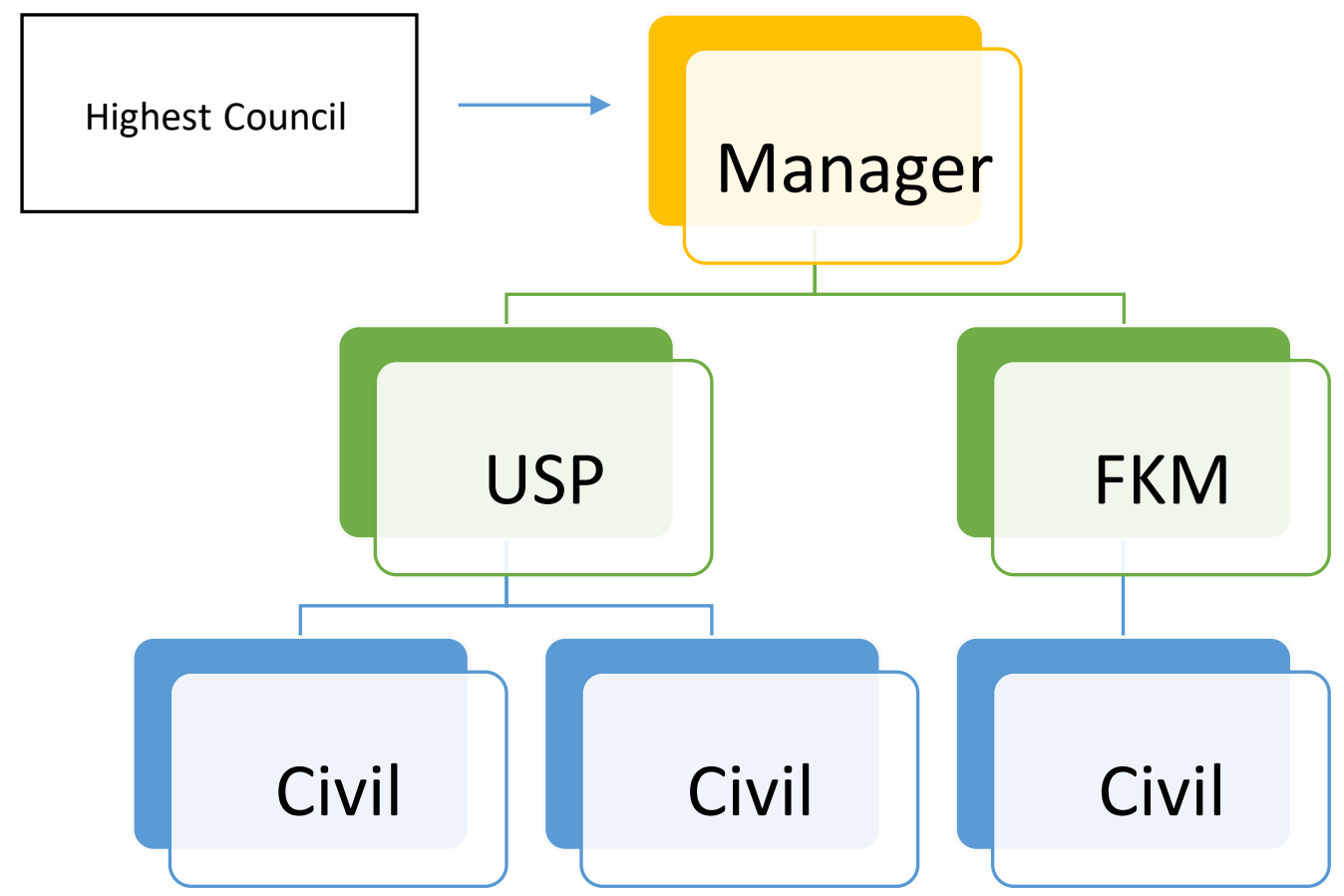

Graphic 5.2 Organization Structure of REC

Cooperatives Council stands for the highest level of power-holder that assigned to supervise the establishment of REC. The members come from representative party such as head of villae (Kades), hamlet (RW), and any other local and external stakeholder. They are appointed by discussion (musyawarah) by cooperative member. The manager task is to regulate all kind of activities in cooperatives. Unit of Saving and loans (re: Unit Simpan Pinjam) assigned to give the loan or credit to the society of developing region and supervision to the local society aabout the urgency of REC. Forum Komunikasi Masyarakat (FKM) assigned to increase society participatory and be responsible for the activities i.e training and education. FKM consists of 'local champion' that is the people who has influency whether it is power, religious stand etc in the region.

\section{Strategic of Funding}

Funding should come from proper relation obtained before, those are government, membership fee, CSR, and donation via crowdfunding or any other funding method. Funding should be allocated as loan to society to build renewable energy power plant from available resource exist on the region, as well as training, education and any other operational.

\subsubsection{Management}

1. Applying efficiency and professional principle in cooperative Cooperative should be established effectively to gain trust from local society. To make the board become more professional, it can be conducted a series of training for them. In other side, the easy access given by bireucracy for funding and capital returning is required to keep the kinship principle. There should be a priority to the society welfare.

2. Managing training and education program

It $s$ required a management to conduct training and education to local society. Management should formulate a propoer curriculum and schedule that match society condition and custom as well as the framework as guidance to formulate key activities. 


\subsubsection{Sustainable Phase}

1. Internalization

This step is needed to strengthen amity of each member. This should be conducted periodically, due to society needs to re-embrace the relation between them and boards. This is aimed to develop kinship principle.

2. Creation of sustainable and innovative program

REC requires high creativity from the boards to realize this point, in kind of encourage SmallIntermediate Society Enterprise (UMKM), "Smart Village" that applies sustainable village system, or any other program that match the needs of society.

3. Expansion

If the cooperative has achieve stablility and reaches an huge number of members, therefore needed an expansion to the nearest region to widen electrification in Indonesia especially developed region.

\subsection{Analysis of the Legal}

Based on the data we obtained, there's no single legal, either in energy or cooperative that stated the REC, whereas cooperatives as an economic instrument, as UU. No. 172012 stated that cooperatives purposed to increase the welfare of its members in specific and society in general. It is a must that government should realize the importance of creating additional legal about REC.. The legal standing could ease the development of renewable energy resources at once the economic development in developing region. However, the creation of renewable energy should be conducted with several discipline of science, those are economic, energy, environment, social and politic. Therefore in this paper we could state the government has the urge to create the law governing this renewable energy because this includes into agenda going to be realized in RUEN.

\section{Conclusion and Suggestion}

One of the solution offered to help the development of the renewable energy in Indonesia is by establishing Renewable Energy Cooperative. The establishment begun with bulding relation, unifying concept in vision and mission creation, the making of the structure and program as well as the funding strategy. Furthermore, in management phase, the boards should establish the program in efficient and professional way. Later in sustainable phase, cooperative should conduct internalization, creating innovative program and doing expansion. However, the establishment of this REC mainly purposed to increase electrification by using the environmental-friendly renewable resources as well as increasing economic of society in developing region. This paper is constructed from other papers by assuming the condition implie in the data equivalent to the condition of developing region. From this thing, we could simply stated that the possibility of inaccuracy of the data should be examined.. Furthermore, this paper should be provided with real data from real society. Therefore the data survey and more objective and more comprehensive study should be conducted to give an high legitimation to this topic we proposed.

\section{References}

C.J. Martin, P. Upham, Grassroots social innovation and the mobilisation of values in collaborative Chambers. Robert. 1996. PRA.Memahami desa secara partisipatif. Yogyakarta. Kanisius.

Compton J.Lin \& Howard Y.McClusky. 1997. "Community Education for Community Development (chapter 14) dalam Ife,J. (1997). Community Development Creating Community Alternatives - vision, analysis and practice. Melbourne: Addison Wesley Longman Australis Limited.

Donny. 2014. Kebijakan Energi dan Lingkungan. Jakarta: LP3S 
Edi Susilo,dkk. 2015. Ironi Negeri Sejuta Nyiur Hijau di Pantai; Pemberdayaan Nelayan dan Pembangunan Maritim di Indonesia. Yogyakarta: Graha Ilmu

ESDM. 2017. Kajian ESDM 2017 . Jakarta.

Moritz and Wolfgang. 2018. Renewable Energy Cooperatives: Facilitating the Energy Transition at Port of Rotterdam. Rotterdam.

Mubyarto,dkk. 2014. Ekonomi Kerakyatan. Jakarta: AIFIS

PT.PLN. 2018. RUPTL PLN 2018 - 2027. Jakarta: PLN

V. Pellicer-Sifres, et al. Learning, transformative action, and grassroots innovation:Insights from the Spanish energy cooperative Som Energia. Energy Research and social science 42 (2018) 1001111 , 